\title{
Symposium on Islamic Epistemology
}

\section{Islam and Epistemology}

\section{Introduction}

On February 27, 1999, the International Institute of Islamic Thought (IIIT) hosted a symposium titled "Islam and Epistemology." The seminar invited many scholars and philosophers to discuss Mehdi Ha'iri Yazdi's book, The Principles of Epistemology in Islamic Philosophy. ${ }^{1}$ The scope of the presentation and discussion was not limited to the contents of the book. Indeed, the book was used as a launching pad for discussions on issues related to epistemology, Islamic sciences, Islamic philosophy, the tensions between reason and revelation, and the differences between the legalistic approach and the philosophical approach. It also raised interesting debates about the similarities and differences between Western-secular and humanist-social sciences and the theocentric discourses of Muslims.

The seminar also doubled as the Second Conference of the Contemporary Islamic Philosophers. Two doctoral students, myself from Georgetown University and Ejaz Akram from Catholic University, organized the first conference in May 1998, at which time we called for a new discourse. ${ }^{2}$ We argued that contemporary Islamic philosophy had become too engaged with writing and rewriting the history of medieval Islamic philosophy without actually doing philosophy. So we invited Muslim intellectuals and philosophers to reflect on the present and advance discourses that will enlighten and improve the present human condition. We argued that Islamic philosophers should play the role of social critics and public intellectuals and assist in thinking of old ideas in new terms and new ideas in old terms. This seminar, in a similar vein, was designed to point the attention of Islamic thinkers toward the need for an empowering and transformative epistemology for contemporary Muslims. ${ }^{3}$

At the seminar, five speakers, each from a different background, made formal presentations. Over 35 students of Islamic philosophy came to the seminar from Virginia, Maryland, New Jersey, North Carolina, New York, and California. Each presentation sought to explore the relationship 
between Islam and epistemology as well as to advance a critical review of Yazdi's book. Dr. Mahdi Aminrazavi, an associate professor of philosophy at Mary Washington College in Virginia, introduced the audience to the traditional background that informed Yazdi's book. Dr. Aminrazavi had taken classes with Dr. Yazdi and has personally known him and his work intimately for over a decade. In a move deliberately designed to provoke the traditional scholars and students of Islam, Dr. Aminrazavi argued that for the philosopher, truth in its entirety was necessarily the function of man's rational faculties. Much to the chagrin of the Sufi-philosophers in the audience, he argued that knowledge can be acquired "by reason and reason alone!" Dr. Aminrazavi gained the audience's approval when he explained in a very lucid fashion the relation between Ibn Sina's metaphor of the suspended man and knowledge by presence. Dr. Aminrazavi's knowledge and deep understanding of Islam's philosophical tradition also helped enlighten the lively discussion that followed the presentations.

Dr. Nasr Arif, an associate professor of political science at the Graduate School of Islamic and Social Sciences in Virginia, was very critical of the book. He argued that it vindicated the accusations that the traditional theologians had made against Islamic philosophers, namely, that they imported and imposed non-Islamic ideas and knowledge forms (such as Greek philosophy) upon Islamic thought. The audience's response to Dr. Arif's presentation was interesting. While the students of Islamic philosophy and mysticism showed open disagreement, the students of fiqh and traditional Islamic sciences could not stop nodding their heads. Dr. Arif's most telling critique was his point that traditionally, Islamic thinkers did not seek to protect truth by developing methodologies. Their focus had always been the development of the mind and the faith of the thinkers and not the structure of thought itself.

Ali Raza Mir, an assistant professor of management at Monmouth University in New Jersey, addressed the issue of Allah's roles in the human quest for knowledge. He introduced the notion of plurality in knowledge forms and suggested that the essence of knowledge by presence lies in the appreciation of the multiplicity of knowledge formations. He also argued that to discuss the issue of epistemology in the current terms of discourse would trap Muslim thinkers into duplicating the Western path to modernity.

Ibrahim Kalin, a Ph.D. student in Islamic philosophy at George Washington University, presented a systematic review of knowledge by 
presence and located it within the larger tradition of Islamic philosophy influenced by Suhrawardi and Mulla Sadra. He clearly agreed with the author and used his presentation to explore the intricacies of knowledge by presence and elaborated its significance to the mystical experience of unification with the divine through the process of self-awareness. Kalin also discussed the importance of the two elements of knowledge, the knower and the known, and explained how these elements were united in knowledge by presence.

As the host and coordinator of the seminar, I began my remarks by discussing the aims of contemporary Islamic philosophers. I was very critical of Yazdi's book and argued that while it was an excellent piece of academic philosophy, it did not contribute much toward empowering contemporary Islamic thought: "Knowledge by presence" is little more than an instinct for self-awareness. In a controversial claim, at least for the Sufi philosophers in the audience, I stated that if knowledge by presence was given its due as described by Yazdi, then it made revelation redundant.

The presentations were followed by an hour and a half of questions, answers, and discussions. The audience was deeply involved and highly informed on the subject. The ensuing battles between the panelists and their interlocutors raised important issues about the importance and the limits of placing epistemology at the center of human thought. The seminar was a great success and it has given a huge impetus to the efforts of the contemporary Islamic philosophers, while shedding new light on epistemology and its relationship to Islam.

M.A. Mugtedar Khan

Visiting Faculty, Washington College, MD

$\mathrm{Ph} . \mathrm{D}$. candidate, Georgetown University

\section{Notes}

1. Mehdi Ha'iri Yazdi, The Principles of Epistemology in Islamic Philosophy: Knowledge by Presence (Albany: State University of New York Press, 1992).

2. See the conference report, Ahmed Iftheqar Hussain, "First Contemporary Islamic Philosopher's Conference," American Journal of Islamic Social Sciences 15, no. 3 ('Fall 1998), 172-176.

3. For a more detailed presentation of this argument, see M.A. Muqtedar Khan, "The Need to Revive Islamic Philosophy," Intellectual Discourse 6, no. 1 (1998), 1-9. 